\title{
WYBRANE UWAGI \\ NA TEMAT CHARAKTERU I STATUSU LEX SPORTIVA W PRZESTRZENI PRAWNOMIĘDZYNARODOWEJ
}

\section{WSTĘP}

W ostatnich trzech dekadach sport, podobnie jak niektóre inne dziedziny ludzkiego życia społecznego, przechodzi intensywny proces globalizacji i komercjalizacji. Skala, liczba i różnorodność imprez sportowych o randze nie tylko olimpijskiej i o zasięgu prawdziwie globalnym nie mają historycznego precedensu. Taki stan rzeczy doprowadził do wykształcenia regulującego sferę globalnego sportu złożonego porządku normatywnego na poziomie ponad- czy też transnarodowym, o zróżnicowanej genezie, mieszanym publiczno-prywatnym charakterze i w znacznej mierze autonomicznego względem autorytetu państwa i innych władz publicznych. Określenie charakteru, statusu i miejsca tego relatywnie młodego porządku normatywnego z perspektywy teorii prawa, a także doktryny prawa międzynarodowego nie jest zadaniem łatwym. Wystarczy zacząć od obserwacji, że problemem jest sama kwestia terminologiczna; pojęcia stojące za nazwami porządek sportowy, globalne prawo sportowe, transnarodowe prawo sportowe czy lex sportiva nie są bynajmniej tożsame. Celem tego artykułu jest poczynienie kilku zasadniczych uwag i propozycji na temat istoty i miejsca materii normatywnej regulującej sport w porządku prawnym społeczności międzynarodowej.

\section{ARCHITEKTURA SYSTEMU SPORTOWEGO I ŹRÓDŁA MIĘDZYNARODOWEGO PORZĄDKU SPORTOWEGO}

Międzynarodowy normatywny system sportowy tradycyjnie postrzegany jest jako zasadniczo prywatnoprawny w swoim charakterze, a nawet, posługując się inną terminologia - pozarządowy. Stwierdzenie takie jest uprawnione zwłaszcza ze względu na instytucjonalne źródła międzynarodowego porządku sportowego, którymi sa przede wszystkim międzynarodowe sportowe organizacje pozarządowe, dysponujace niejednokrotnie szeroka autonomia w przestrzeni narodowej i transnarodowej. Dwa dominujace filary globalnego po- 
rządku sportowego - ruch olimpijski oraz ruch antydopingowy sa zbudowane właśnie wokół cieszących się autorytetem struktur pozarządowych ${ }^{1}$.

Jednakże ten wydawałoby się prywatny porządek prawny w wielu aspektach jest silnie regulacyjny i dysponuje efektywnymi metodami egzekwowania swoich norm, głównie za pomocą sankcji organizacyjnych stosowanych przez federacje sportowe. Istnieją też $\mathrm{w}$ końcu obszary funkcjonalnie należące do międzynarodowego prawa sportowego, a jednak opierające się na prawie publicznym lub wręcz stanowiące element gałęzi prawa publicznego - narodowego oraz międzynarodowego. Jeśli bowiem przyjrzeć się, jakie zagadnienia obejmuje doktrynalne pojęcie prawa sportowego, o czym można łatwo zyskać wyobrażenie, przeglądając treść podręczników wprowadzających do tej dziedziny, okaże się, że spektrum tematyczne jest bardzo szerokie. Poza kwestiami instytucjonalnymi i stowarzyszeniowymi, prawem antydopingowym czy prawem umów oraz czynów niedozwolonych, do podstaw prawa sportowego zalicza się kwestie zwiąane z takimi dziedzinami, jak: prawo pracy, prawo własności intelektualnej, prawo mediów, prawo gospodarcze i podatkowe, prawo antymonopolowe, a także prawa człowieka, w tym prawo antydyskryminacyjne oraz szereg gwarancji konstytucyjnych związanych ze statusem sportowca ${ }^{2}$. Może to w ogóle rodzić pytanie, czy osobna gałąź pod nazwą prawo sportowe w ogóle istnieje; niektórzy autorzy twierdza, że należy raczej mówić o „prawie i sporcie” (law and sports $)^{3}$. Niewątpliwie gałąź ta nie jest wyodrębniona według jednoznacznych klasycznych kryteriów, takich jak metoda czy przedmiot regulacji. Jak trafnie zwraca się uwagę, szeroko ujmowane prawo sportowe wyróżniane jest także ze względów historycznych, kulturowych i praktycznych ${ }^{4}$, czy też po prostu funkcjonalnych. Jest to zatem porządek normatywny o charakterze mieszanym, wykorzystujący na różnych poziomach krajowych, regionalnych i międzynarodowych narzędzia zarówno publiczno- jak i prywatnoprawne.

W sferze ponadnarodowej (globalnej), będącej głównym przedmiotem zainteresowania niniejszej analizy, porządek sportowy ma charakter genetycznie pozarządowy, jednakże wydaje się, że szereg narzędzi normatywnych oraz instytucji egzekwowania norm, o których będzie mowa poniżej, mimo swej prywatnoprawnej proweniencji nie daje się w pełni wytłumaczyć bez odwołania

${ }^{1}$ W przypadku Ruchu Olimpijskiego centralną organizacją jest Międzynarodowy Komitet Olimpijski, a instrumentem normatywnym - Karta Olimpijska. W ramach sieci olimpijskiej funkcjonują także międzynarodowe federacje sportowe dla poszczególnych dyscyplin, narodowe komitety olimpijskie (np. Polski Komitet Olimpijski), a także komitety organizacyjne przygotowujace zawody olimpijskie. Wszystkie organizacje sa pozarządowe. Podobnie w przypadku ruchu antydopingowego Światowa Agencja Antydopingowa (WADA) jest fundacja prawa szwajcarskiego; centralnym instrumentem normatywnym o znaczeniu globalnym jest w tym zakresie Światowy kodeks antydopingowy; zob. M. F. Mazzucco, Lex Sportiva: Sports Law as a Transnational Autonomous Legal Order, niepubl., passim.

${ }^{2}$ Zob. G. M. Wong, Essentials of Sports Law, Praeger, Santa Barbara-Denver-Oxford 2010; P. K. Thornton, Sports Law, Jones and Bartlett Publishers, Boston-Toronto-London-Singapore 2011; M. Beloff, T. Kerr, M. Demetriou, Sports Law, Hart Publishing, Oxford 1999.

${ }^{3}$ Zob. T. Davis, What is sports law?, w: R. C. R. Siekmann, J. Soek (eds.), Lex Sportiva: What Is Sports Law?, Springer, The Hague 2012, s. 3 i n.

${ }^{4}$ J. A. R. Nafziger, International sports law, w: R. Wolfrum (ed.), The Max Planc Encyclopedia of Public International Law, styczeń 2009, www.mpepil.com [dostęp: 23.08.2013]. 
do publicznoprawnych sposobów regulacji i metod interpretacji 5 . W literaturze przedmiotu wskazuje się zwłaszcza na korzystanie przez porządek sportowy $\mathrm{z}$ tzw. ius commune, a zatem ogólnych zasad prawa międzynarodowego ${ }^{6}$ czy też precyzyjniej - norm powszechnego prawa międzynarodowego publicznego.

W odniesieniu do zakresu przedmiotowego i źródeł prawa sportowego, a w konsekwencji dla przybliżenia jego charakteru normatywnego, zasadnicze znaczenie mają kwestie terminologiczne. Nie bez przyczyny użyto powyżej określenia „porządek sportowy”, które to sformułowanie pojawiało się już w literaturze prawnomiędzynarodowej ${ }^{7}$, jednakże w niezbyt precyzyjnie określonym kontekście, m.in. jako synonim lex sportiva. Moim zdaniem określenie porządek sportowy powinno mieć najszersze znaczenie i odnosić się do ogółu wszelkich norm oraz systemu instytucji regulujących aktywność i działalność w dziedzinie sportu. Nie ulega bowiem wątpliwości, że na tak zdefiniowany porządek sportowy składają się przede wszystkim różne systemy normatywne, a także nienormatywne regulatory zachowań, takie jak choćby silnie akcentowana historia sportu i starożytne oraz nowożytne tradycje ruchu olimpijskiego, będące fundamentem jego aksjologii. Wśród systemów normatywnych, z którymi mamy do czynienia $\mathrm{w}$ odniesieniu do sportu na poziomie ponadnarodowym, niewątpliwie na pierwszy plan wychodza normy prawne; jak wskazano powyżej, poza normami tworzonymi autonomicznie chociażby przez organizacje pozarządowe ruchu olimpijskiego, w skład porządku sportowego wchodzą bez wątpienia normy ogólnego prawa międzynarodowego publicznego, określane mianem ius commune. Obok wymienionych pewne znaczenie odgrywać może także tzw. prawo wspólne, które formalnie i genetycznie należy do porządków prawnych państw, jednakże jest ono w dużym stopniu ujednolicone lub zharmonizowane, co sprawia, że odgrywa rolę na poziomie międzynarodowym. Wpływ na sytuację prawną konkretnych federacji i poszczególnych sportowców mają także z pewnością narodowe porządki prawne, a także inne reżimy, jak choćby prawo Unii Europejskiej.

Poza normami prawnymi w ramach porządku sportowego mamy jednak do czynienia niewątpliwie z innymi systemami normatywnymi o szczególnym znaczeniu dla sportu; najważniejsze wśród nich wydają się normy etyczne oraz słusznościowe (np. reguły fair play), a także reguły techniczne czy też zasady gry w sporcie. Obie grupy - reguły gry i fair play - zostały w literaturze i orzecznictwie określone łącznie mianem lex ludica ${ }^{8}$. Cechą charakterystyczną

${ }^{5}$ Podobnie L. Casini, The making of a lex sportiva by the Court of Arbitration for Sport, „German Law Journal" 12(5), 2011, s. 1317-1318.

${ }^{6}$ K. Foster, Is there a global sports law?, w: R. C. R. Siekmann, J. Soek (eds.), op. cit., s. 37; zob. też K. Foster, Is there a global sports law?, „Entertainment Law” 2(1), 2003, s. 1-18; ius commune jest w tym sensie pewną grupą norm-zasad wyodrębnianych czasem koncepcyjnie w teorii prawa międzynarodowego, samo w sobie nie jest jednak zasada, jak błędnie wskazuje P. Łebek, Autonomia organizacji sportowych, „Problemy Współczesnego Prawa Międzynarodowego, Europejskiego i Porównawczego" 9, 2011, s. 158.

7 Zob. P. Łebek, op. cit., s. 153-181.

${ }^{8}$ K. Foster, Lex sportiva and lex ludica: the Court of Arbitration for Sport's Jurisprudence, „Entertainment and Sports Law Journal” 2006, http://go.warwick.ac.uk/eslj/issues/volume3/number2/foster/ [dostęp: 3.01.2015], Nb. 8. 
tego sytemu normatywnego jest jego niezależność (autonomia) od prawa. Powszechnie przyjęta w orzecznictwie zasada nakazuje uznać zwłaszcza reguły gry za - co do zasady - wolne od ingerencji prawnej, chyba że maja charakter rażąco błędny, kapryśny lub złośliwy ${ }^{9}$. Żadne ciało judykacyjne o charakterze organu rewizyjnego nie jest bowiem w lepszej pozycji do rozstrzygnięcia sporu o zastosowanie reguł gry niż arbitrzy nadzorujący rywalizację w polu gry ${ }^{10}$. Mają one zresztą fundamentalnie inny charakter niż normy prawne przede wszystkim ze względu na swoją niemal całkowitą arbitralność i czysta konwencjonalność; ponadto nie posiadają jakiejkolwiek społecznej ratio legis, sa w zasadzie całkowicie heteronomiczne, uzasadnienie ich obowiazywania jest wyłącznie tetyczne, a także co najmniej w pewnym zakresie tworzą autopojetyczny ${ }^{11}$ system normatywny. W związku z tym zasadne wydaje się użycie terminu „światowy porządek sportowy” jako obejmującego wszystkie normatywne regulatory sportu w wymiarze globalnym, niekoniecznie - jak widać ograniczajace się tylko do norm prawnych.

Z kolei określenie system sportowy powinno odnosić się do trudno uchwytnego z perspektywy czysto normatywnej, a w globalnym sporcie bardzo istotnego systemu instytucjonalnego organizacji i organów, będących zarówno źródłem normatywnym, jak i przedmiotem regulacji w ramach porządku sportowego. Można do nich zaliczyć wymieniane już wyżej typy organizacji, takie jak międzynarodowe federacje sportowe, MKOL oraz narodowe komitety olimpijskie, a także krajowe samorządne organizacje sportowe (np. PZPN) ${ }^{12}$. Do owej sieci instytucjonalnej należy oczywiście zaliczyć także aparat stosowania norm porząlku sportowego, silnie oparty na organach arbitrażowych, w tym przede wszystkim na Trybunale Arbitrażowym dla Sportu (Court of Arbitration for Sport - CAS). System ten nie jest zbudowany na zasadzie hierarchii; raczej mamy w ramach niego do czynienia z pewną heterarchiczną siecią zarządzająca sportem, która wykształciła własne reguły kolizyjne rozwiązywania konfliktów pomiędzy wchodzącymi w jej skład ośrodkami ${ }^{13}$.

Wydaje się, że zasadniczo w codziennym życiu sportowym obowiązuje zasada subsydiarności, gdyż to przede wszystkim narodowe organizacje sportowe odpowiedzialne sa za rozwiązywanie sporów oraz sankcjonowanie nadużyć. Spory te mogą być rozwiązywane także na poziomie międzynarodowych branżowych federacji sportowych, a w przypadku sporów kompetencyjnych lub merytorycznych pomiędzy organizacjami narodowymi a międzynarodowymi rozstrzygnięcia są dostarczane przez system arbitrażowy, w którym kluczową rolę odgrywa $\mathrm{CAS}^{14}$. Podobnie w systemie olimpijskim podstawowa zasada

${ }^{9}$ Zob. orzeczenie Trybunału Arbitrażowego dla Sportu z 21 października 2004 r.: Yang Tae Young and Korean Olympic Committee v International Gymnastics Federation [FIG], CAS Award 2004/A/704.

${ }^{10}$ Zob. ibidem, par. 12.

${ }_{11}$ Zob. S. Sykuna, Autopojeza, w: Leksykon wspótczesnej teorii i filozofii prawa. 100 podstawowych pojęć, red. J. Zajadło, C. H. Beck, Warszawa 2007, s. 22-23.

12 J. A. R. Nafziger, op. cit., pkt 31-36.

${ }^{13}$ Por. ibidem, pkt 32.

${ }^{14}$ Zob. np. orzeczenie z 5 stycznia 1995 r.: Advisory Opinion at the Request of UCI and CONI, CAS 94/128. 
pomocniczości preferuje narodowe komitety olimpijskie w rozwiąywaniu szeregu lokalnych lub krajowych problemów. Decyzje w sprawach olimpijskich podejmować mogą także międzynarodowe federacje sportowe. Jednakże najwyższą władzę i autorytet w zakresie rozwiązywania sporów w ramach całego ruchu olimpijskiego zachowuje $\mathrm{MKOL}^{15}$. Autonomia norm lex sportiva ma tak szeroki zasięg oddziaływania, że nawet sądy systemów common law (np. w USA i Wielkiej Brytanii), poza wybranymi kwestiami m.in. z zakresu prawa pracy, odmawiaja rozpoznawania wielu sporów i powództw wytaczanych przeciwko federacjom, ustępując pola rozwiązaniom arbitrażowym w ramach systemu sportowego ${ }^{16}$.

W obliczu powyższych uwag także wyjątkowo heterogeniczny musi być system źródeł norm porządku sportowego, pochodzących od ośrodków wchodzących w skład owego złożonego systemu sportowego. W doktrynie za kluczowy instrument lex sportiva uznaje się Kartę olimpijską ${ }^{17}$, stanowiącą do pewnego stopnia swoistą konstytucję systemu sportowego. Jest to najważniejsze źródło norm o charakterze całkowicie prywatnoprawnym, wydawane autonomicznie przez MKOL. Jednakże kluczowy dokument ruchu antydopingowego, Światowy kodeks antydopingowy (World Anti-Doping Code) został przyjęty przez bardzo szczególną ze względu na swoją genezę Światową Agencję Antydopingowa (World Anti-Doping Agency, WADA). Jest ona fundacja prawa szwajcarskiego o charakterze organizacji międzynarodowej, przy czym w skład jej władz wchodzą na równi przedstawiciele federacji i organizacji sportowych, jak i przedstawiciele rządów ${ }^{18}$. Jest więc organizacją o mieszanym pozarządowo-międzyrządowym statusie. Również Światowy kodeks antydopingowy należy postrzegać jako specyficzny dokument normatywny - w zasadzie prywatny, jednakże w części czerpiący swój autorytet także z ustanowienia państw. Obok wyżej wymienionych przykładów źródeł lex sportiva, do których zaliczyć należy także wewnętrzne prawo wtórne organizacji sportowych i orzecznictwo trybunałów międzynarodowych, a także prawo zwyczajowe i ogólne zasady prawa ${ }^{19}$, w skład źródeł porządku sportowego wchodzą także typowe instrumenty stanowiące źródła prawa międzynarodowego publicznego. Jako przykłady należy tutaj wymienić chociażby Międzynarodową konwencję o zwalczaniu dopingu w sporcie z 19 października 2005 r. ${ }^{20}$, natomiast z istotnych dla systemu sportowego ogólnych źródeł prawa międzynarodowego nieodnoszących się jednak wyłącznie lub szczegółowo do problemów sportu, wskazać należy kluczową dla efektywności orzeczeń CAS Konwencję o uznawaniu i wykonywaniu zagranicznych orzeczeń arbitrażowych sporządzoną w Nowym Jorku 10 czerwca 1958 r. (tzw. konwencja nowojorska) ${ }^{21}$.

${ }_{15}$ J. A. R. Nafziger, op. cit., pkt 33-36.

${ }^{16}$ Zob. ibidem, pkt 15.

${ }^{17}$ Zob. Karta olimpijska, http://olimpijski.pl/pl/files/Download/Karta_olimpijska_PL.pdf [31.08.2013].

${ }^{18}$ Zob. informacje na stronie WADA: http://www.wada-ama.org/en/About-WADA/History/ WADA-History/ [dostęp: 3.01.2015].

${ }^{19} \mathrm{~K}$. Foster, Is there..., s. 41-42.

${ }^{20}$ Dz. U. 2007, Nr 142, poz. 999.

${ }^{21}$ Dz. U. 1962, Nr 9, poz. 42. 


\section{PRÓBY DEFINICJI I ZAKRES NORMATYWNY LEX SPORTIVA}

Powyższa analiza struktury normatywnej międzynarodowego porządku i systemu sportowego może jednak pozostawiać wątpliwości co do zakresu znaczenia terminu lex sportiva, używanego zresztą często w sposób intuicyjny. Wynika to w dużej mierze z pewnej niedookreśloności samego pojęcia, a także znacznych różnic co do jego definicji w doktrynie. Sama geneza terminu, co do czego panuje zgodność w literaturze przedmiotu, w jednoznaczny sposób nawiąuje do pokrewnego pojęcia lex mercatoria lub prawo kupieckie. Termin ten oznacza „grupę pozanarodowych norm prawnych i zasad, które są tworzone przede wszystkim przez międzynarodową wspólnotę kupiecką bazująca na zwyczaju, praktyce przemysłowej i ogólnych zasadach prawa, znajdujących zastosowanie do międzynarodowego arbitrażu handlowego w celu regulowania transakcji pomiędzy podmiotami prywatnymi, a także pomiędzy nimi a państwami w toku transgranicznej sprzedaży, handlu i obrotu finansowego" ${ }^{2}$. Rysuje się tutaj oczywista analogia porządku sportowego do systemu międzynarodowego prywatnego prawa handlowego. Obie dziedziny sa bowiem, jak się wskazuje, w znacznej mierze autonomiczne i niezależne od bezpośredniej regulacji oraz interwencji adjudykacyjnej ze strony państwa, tworzone są głównie przez samych uczestników na bazie praktyki w danej dziedzinie i własnych źródeł normatywnych (odpowiednio np. zwyczaje handlowe i reguły rywalizacji sportowej), instrumentów prywatnoprawnych (kontrakt) przy wsparciu kluczowych umów międzynarodowych, a także posiadają rozwinięty, wewnętrzny system rozwiązywania sporów oparty na arbitrażu ${ }^{23}$. Jednakże status i zakres koncepcji lex mercatoria jest także sporny i mimo tradycji prawa kupieckiego sięgającej średniowiecza, granice tego pojęcia nie sa jednolicie rozumiane w doktrynie ${ }^{24}$.

Analogicznie rzecz ma się w przypadku lex sportiva. Różnice zdań dotycza przy tym nie tylko zakresu, lecz także w ogóle samego charakteru prawnego i miejsca tego systemu normatywnego w strukturze prawnomiędzynarodowej. Co do zakresu pojęcia, według niektórych autorów lex sportiva ogranicza się jedynie do prawa arbitrażowego, a zatem zasad wynikających z orzecznictwa, przy czym kluczową rolę odgrywa wspomniany już wyżej Trybunał Arbitrażo-

${ }^{22}$ S. W. Shill, Lex mercatoria, w: R. Wolfrum (eds.), The Max Planc Encyclopedia of Public International Law, kwiecień 2011, www.mpepil.com [dostęp: 31.08.2014], pkt 1.

${ }^{23}$ Por. K. Foster, Is there..., s. 45-47, jednakże warto zauważyć, że autor ten ostatecznie dochodzi do konkluzji (s. 50), iż analogia pomiędzy lex sportiva a lex mercatoria jest fałszywa, ponieważ z perspektywy socjologicznej lex sportiva nie bazuje na prawdziwym kontrakcie, gdyż pozycje odpowiednio sportowca i potężnych federacji sportowych nie sa w takim stosunku prawnym równoważne. Polemika z tym poglądem nie jest w tym miejscu możliwa ani też przesądzanie tej kwestii nie wydaje się kluczowe z perspektywy głównego celu tego artykułu. Dość jednak powiedzieć, że porównanie jest z teoretycznej perspektywy wystarczająco uzasadnione i analitycznie użyteczne; por. B. Kolev, Lex sportiva and lex mercatoria, „The International Sports Law Journal" 2008, http://www.thefreelibrary.com/Lex+sportiva+and+Lex+Mercatoria.-a0212546177 [dostęp: 3.01.2015].

${ }^{24}$ Zob. S. W. Shill, op. cit., pkt 3. 
wy dla Sportu (CAS) ${ }^{25}$. W tym znaczeniu także równa się często lex sportiva z pojęciem międzynarodowego prawa sportowego czy też traktuje jako podgałąź tak określonej subdyscypliny prawa międzynarodowego publicznego.

Wydaje się, że jest to jednak obecnie zbyt konserwatywny pogląd, gdyż wraz z dynamicznym rozwojem systemu sportowego coraz większego znaczenia nabiera nie tylko orzecznictwo arbitrażowe, lecz także ogół norm tworzonych przez prywatnoprawne pozarządowe organizacje sportowe. Dlatego też w szerszym tzw. transnarodowym ujęciu lex sportiva obejmuje całość norm kreowanych przez te gremia, łącznie z orzecznictwem arbitrażowym CAS i innych instytucji rozwiązywania sporów w sporcie ${ }^{26}$.

W końcu wydaje się, że można wyróżnić najszersze znaczenie lex sportiva jako globalnego prawa sportu. Różnica między tym a poprzednim znaczeniem nie odnosi się tyle do zakresu źródeł normatywnych, które wchodzić miałyby w skład lex sportiva, co raczej podkreśla szczególny ponadnarodowy charakter tego systemu. W tym znaczeniu bowiem lex sportiva obejmuje całe prawo i orzecznictwo pochodzace od funkcjonujących w przestrzeni międzynarodowej (czy też ponadnarodowej) pozarządowych organizacji i instytucji sportowych, jednakże akcent położony jest na szczególne znaczenie odrębnych zasad sportowych (principia sportiva) i kształtujacych się oryginalnych koncepcji doktrynalnych, wykładanych najczęściej w orzecznictwie $\mathrm{CAS}^{27}$. W tym znaczeniu podkreśla się także szeroko rozumianą autonomię lex sportiva jako jej fundamentalna Grundnorm, a także wyraźnie oddziela jej przedmiot zainteresowania od międzynarodowego prawa sportowego opartego bądź to na prawie wspólnym międzypaństwowym uzyskanym w drodze komparatystycznej czy też od klasycznych, wymienianych wyżej przykładowo, źródeł prawa międzynarodowego publicznego. Natomiast zdecydowanie nietrafne, nieczytelne i wynikajace z pozytywistycznego zafiksowania na koncepcji testu pochodzenia (test of pedigree) ${ }^{28}$ jest stawianie lex sportiva $\mathrm{w}$ opozycji do „prawa sportowego", a zatem w przestrzeni pozaprawnej, czy też równanie tego terminu z przybliżonym wyżej pojęciem porządku sportowego ${ }^{29}$.

\section{CHARAKTER PRAWNY LEX SPORTIVA}

Czy lex sportiva może być zatem określona mianem prawa globalnego? Czy i jak różni się to pojęcie od bliskiego mu, a nawet często używanego zamiennie „prawa transnarodowego” i dlaczego używanie przymiotnika „międzynarodowy” niekoniecznie jest adekwatne w kontekście przedmiotu tej analizy? Jak zauważa Roman Kwiecień, „pojęcie prawa transnarodowego jest najszerszym

${ }^{25}$ J. A. R. Nafziger, op. cit., pkt 47-48; por. także J. A. R. Nafziger, Lex sportiva, w: R. C. R. Siekmann, J. Soek (red.), op. cit., s. 53 i n.

${ }^{26}$ L. Casini, op. cit., s. 1319.

${ }^{27}$ K. Foster, Lex sportiva: transnational law in action, w: R. C. R. Siekmann, J. Soek (red.), op. cit., s. 243-244; K. Foster, Is there..., s. 41-42 i 43-47; por. L. Casini, op. cit., passim.

${ }_{28}$ Zob. H. L. A. Hart, The Concept of Law, 2nd ed., Clarendon Press, Oxford 1994, s. 265.

29 Tak P. Łebek, op. cit., s. 158-159. 
z pojęć używanych na określenie prawa występującego w obrębie społeczności międzynarodowej”30.

Rozróżnienie prawa „między-” i „transnarodowego” pojawiło się dość wcześnie, ponieważ już na początku rozwoju współczesnego systemu prawa międzynarodowego w latach pięćdziesiątych XX w., a za autora tej koncepcji uznaje się powszechnie Philipa C. Jessupa ${ }^{31}$. Wprowadzenie tego pojęcia było wyrazem próby nazwania pewnej grupy problemów, jakie stopniowo zaczęły pojawiać się w powojennym porządku prawomiędzynarodowym, a które sprawiały, że klasyczne rozumienie prawa międzynarodowego jako „prawa między narodami” (ius inter gentes) powoli przestawało wystarczać do oddania charakteru jego ewolucji. Terminem prawo transnarodowe próbowano objaćc efekt stosowania wszelkich norm prawnych odnoszacych się do elementu obcego, zagranicznego czy międzynarodowego i wywołujacych skutki nieograniczone jedynie do obszaru pojedynczej terytorialnej jurysdykcji. Ponadto zaczęło pojawiać się zjawisko aktywności prawotwórczej lub szerzej normotwórczej innych podmiotów niż państwa - z początku organizacji międzynarodowych, a później także prywatnych organizacji pozarządowych, podmiotów gospodarczych (korporacji handlowych, przemysłowych działajacych w wielu państwach jednocześnie i poza obszarem jurysdykcji państwowej), a także jednostek. W końcu pojęcie transnarodowości oddaje wzrastające znaczenie prawa międzynarodowego prywatnego i kreowanych przez nie stosunków prawnych, co ma szczególne odniesienie do takich reżimów, jak wspomniana wyżej lex mercatoria.

Przypisanie lex sportiva charakteru prawa typu transnarodowego jest nie do końca trafne przede wszystkim ze względu na szerokie konwencjonalne konotacje semantyczne wymienione powyżej ${ }^{32}$. Słuszna jest uwaga, że zakres znaczeniowy koncepcji „transnarodowości”, mimo iż atrakcyjny z deskryptywnego punktu widzenia, jest zbyt szeroki, aby stanowić przydatne narzędzie analityczne lub poznawcze ${ }^{33}$. Rozmyciu wydaje się ulegać przy użyciu tego określenia jednoznacznie międzynarodowa czy tė̇ wręcz ponadnarodowa geneza trzonu norm wchodzacych w skład lex sportiva, a przede wszystkim silna autonomia i wewnętrzna konstytucyjna struktura tego systemu normatywnego. Z kolei in plus dla użycia pojęcia transnarodowości należy zaliczyć zwrócenie uwagi na prywatnoprawną genezę lex sportiva i dominującą rolę normodawców pozapaństwowych.

Czy zatem trafniejsze jest użycie określenia prawo globalne w odniesieniu do lex sportiva? Odpowiedź na to także nie jest jednoznaczna. W teorii i filozofii prawa międzynarodowego pojęcie uniwersalizmu lub globalizmu ma

${ }^{30}$ R. Kwiecień, Teoria i filozofia prawa międzynarodowego. Problemy wybrane, Difin, Warszawa 2011, s. 70; szeroko na temat społeczności międzynarodowej i jej systemu normatywnego zob. T. Widłak, Wspólnota międzynarodowa, Wydawnictwo Uniwersytetu Gdańskiego, Gdańsk 2012.

${ }^{31}$ Ph. C. Jessup, Transnational Law, Yale University Press, New Haven 1956.

32 Zob. aprobująco na temat określenia prawa sportowego mianem transnarodowego wypowiada się F. Latty, Transnational sports law, w: R. C. R. Siekmann, J. Soek (red.), op. cit., s. 273285 .

${ }^{33}$ R. Kwiecień, op. cit., s. 70-71. 
różne znaczenia i łączy się z wieloma prądami i kierunkami myśli prawniczej. W tradycyjnym ujęciu podkreśla się aspekt istnienia kompletnego, spójnego i samodzielnego porządku prawnego operujacego w wymiarze uniwersalnym, w znacznej mierze niezależnego walidacyjnie od woli pojedynczych państw lub innych aktorów, którego źródła są w zasadzie wyłącznie genetycznie międzynarodowe (a w każdym razie pozbawione w znacznej mierze wpływów etatystycznych).

Przede wszystkim jednak jest to porządek budowany z myślą o jednostce ludzkiej i jej godności jako ostatecznym moralnym celu; również człowiek jest dla prawa globalnego fundamentalnym i pierwotnym podmiotem, a nie przedmiotem jak w klasycznym prawie międzynarodowym. W tym kontekście „prawo globalne” jest oczywiście jedynie pewnym typem idealnym in statu nascendi lub postulatem normatywnym. W przypadku lex sportiva pojęcie prawa globalnego oddaje lepiej daleko posuniętą autonomię, wyrażająca się choćby w quasi-konstytucyjnych i doktrynotwórczych orzeczeniach $\mathrm{CAS}^{34}$ oraz podkreśla zdecydowanie priorytetowe znaczenie regulatorów o genezie ponadnarodowej przed źródłami narodowymi czy międzynarodowymi w tradycyjnym znaczeniu. Z drugiej jednak strony wydaje się, że określenie to jest nieco zbyt obciążone aksjologicznie, odwołuje się raczej do prawa powszechnego i porządku uniwersalnego i w związku z tym nie jest adekwatne do oznaczania dziedziny (reżimu) co prawda społecznie istotnej, ale jednak przedmiotowo dość szczególnej i funkcjonalnie ograniczonej. Z kolei określenie „prawo ponadnarodowe" (supranational law) jest doktrynalnie związane ściśle z historią regionalnej europejskiej integracji wokół Wspólnot Europejskich, a obecnie Unii Europejskiej ${ }^{35}$. Nosi ono co prawda w sobie adekwatny do przedmiotu niniejszej analizy potencjał semantyczny, zwraca bowiem uwagę na rzeczywista dosłownie ponadnarodowa autonomię lex sportiva, jest jednak zbyt ściśle związane doktrynalnie ze zdecydowanie publicznoprawnym typem reżimu czy też organizacji międzynarodowej.

Najtrafniejsze wydaje się określenie lex sportiva jako pewnego typu systemu normatywnego mieszczącego się w kategorii globalnego prawa administracyjnego. Pojęcie to zaczęło kształtować się na przestrzeni mniej więcej ostatniej dekady na określenie fenomenu prawa związanego z globalnym zarządzaniem (global governance), a zatem „administrowaniem” stosunkami międzynarodowymi za pomocą narzędzi nieograniczających się jedynie do struktur międzyrządowych ${ }^{36}$. Globalne prawo administracyjne obejmuje zarówno klasyczne międzynarodowe prawo instytucjonalne, regulujące funkcjonowanie organizacji międzynarodowych, jak i międzynarodową działalność narodowych organów (agencji) administracji publicznej, a także funkcjono-

${ }^{34}$ L. Casini, op. cit., passim.

35 Zob. A. Skordas, Supranational law, w: R. Wolfrum (ed.), The Max Planc Encyclopedia of Public International Law, marzec 2011, www.mpepil.com [dostęp: 31.08.2014].

36 B. Kingsbury, M. Donaldson, Global administrative law, w: R. Wolfrum (ed.), The Max Planc Encyclopedia of Public International Law, kwiecień 2011, www.mpepil.com [dostęp: 10.09.2014]. 
wanie transnarodowych organizacji pozarządowych i hybryd oraz sieci tych instytucji, tworzących łącznie tkankę „globalnej administracji” ${ }^{37}$.

Globalne prawo administracyjne ma więc zróżnicowaną strukturę, w ramach której, dokładnie tak jak w przypadku lex sportiva, elementy publiczne przenikają się z prywatnymi, a reżimy zbudowane wokół instytucji pozarządowych często upodobniają swoje mechanizmy działania do tych znanych z publicznoprawnych, administracyjnych sposobów podejmowania decyzji ${ }^{38}$. Jednym ze źródeł globalnego prawa administracyjnego mogą być właśnie wewnętrzne normy generowane przez autonomiczne systemy, rozumiane wedle teorii systemów Niklasa Luhmanna jako funkcjonalne wspólnoty zaangażowane w powtarzające się racjonalne praktyki (np. administracyjne), same w sobie legitymizujące swoje wewnętrzne reguły jako prawo. Takim systemem jest według Gunthera Teubnera ${ }^{39}$ lex mercatoria; w drodze analogii cechy te łatwo przypisać także lex sportiva. Jest on autonomiczny w tym sensie, że nie wymaga legitymizacji państwa do uznania prawnego charakteru jego wewnętrznych reguł ani ich egzekwowania, a także uznaje tworzenie prawa przez umowę prawotwórczą pomiędzy prywatnymi partnerami (dodajmy w tym miejscu: instytucjami czy tė̇ agendami administracyjnymi takiego reżimu) jako sposób równy prawu precedensowemu czy zwykłej legislacji. W efekcie mamy do czynienia z niemal autopojetycznym systemem-reżimem o charakterze administracyjnym lub quasi-administracyjnym, przynajmniej jeśli chodzi o sposób zarządzania, co jest widoczne w modus operandi systemu sportowego i relacji pomiędzy poszczególnymi federacjami sportowymi, funkcjonujacymi na różnych szczeblach.

\section{PODSUMOWANIE: LEX SPORTIVA JAKO LEX FERENDA}

Ograniczone ramy niniejszej analizy nie pozwalają na dogłębne zbadanie powyższych założeń w odniesieniu do lex sportiva. Trzeba jednak przyznać, że przynajmniej prima facie propozycja ukazania reżimu sportowego na poziomie ponadnarodowym w kontekście globalnego prawa administracyjnego jest godna uwagi i stanowi atrakcyjna propozycję wskazania miejsca i charakteru lex sportiva w przestrzeni prawnomiędzynarodowej, wolną od ograniczeń narzucanych przez starsze koncepcje i tradycyjną terminologię. Z perspektywy teorii prawa system i porządek sportowy odznaczają się w sensie normatywnym bardzo szczególnymi a zarazem interesującymi cechami.

${ }^{37}$ Zob. ibidem, pkt 15-19.

${ }^{38}$ Porządek sportowy nie byłby zresztą tutaj jedynym przykładem tego zjawiska; można wskazać choćby na reżimy zarządzania w sferze Internetu zbudowane wokół takich organizacji, jak Internet Corporation for Assigned Names and Numbers (ICANN) - agendę w swej genezie pozarządowa, zarządzającą protokołami adresowymi.

${ }^{39}$ G. Teubner, Global Bukowina: legal pluralism in the world society, w: idem (ed.), Global Law Without a State, Dartmouth Publishing, Bookfield, Vermont 1997, s. 11. 
Porządek sportowy jest w znacznej mierze autonomiczny, a nawet w pewnych kontekstach może być postrzegany jako autopojetyczny, składa się nie tylko z reguł pierwszego stopnia, ale także dysponuje swoimi regułami drugiego stopnia, w tym przede wszystkim własną reguła uznania. W konsekwencji w jego skład wchodzą nie tylko normy prawne, ale także inne specyficzne, takie jak normy lex ludica zawierajace reguły techniczne lub reguły fair play, stanowiące równorzędne z normami prawnymi źródło normatywne; przy czym ukształtowały się reguły kolizyjne dajace niejednokrotnie lex ludica pierwszeństwo przed normą stricte prawną. Źródła norm prawnych lex sportiva sa bardzo zróżnicowane i zakotwiczone także w krajowych i klasycznych międzynarodowych aktach prawnych. Sam system sportowy ma złożona, heterarchiczną i niemal konstytucyjnie uporządkowaną strukturę (ze względu na autorytet i legitymizację Karty olimpijskiej i MKOL) o wyraźnym oddziaływaniu w obszarze sportu na skalę globalną nawet na poziomie narodowym, przy czym autorytet głównych ponadnarodowych instytucji prywatnoprawnych często przełamuje wolę organów krajowej władzy publicznej. Centralną rolę dla rozwoju własnej jurysprudencji i kształtowania własnej tożsamości oraz ochrony autonomii lex sportiva odgrywa wysoce efektywny aparat arbitrażowy z CAS na czele. System sportowy jest zorganizowany po części na sposób administracyjnoprawny, choć granice pomiędzy sferą prywatna a publiczna zdecydowanie się zacierają.

Mimo wszystko wydaje się, że nie należy zbyt pochopnie próbować określić międzynarodowy porządek sportowy ani lex sportiva jako sui generis reżim w przestrzeni prawnomiędzynarodowej. Można zaryzykować nieco być może spekulatywną tezę, że ten peryferyjny w istocie rezim (z perspektywy teorii prawa i dogmatyki prawa międzynarodowego) jest tak naprawdę swoista lex ferenda, pewna zapowiedzią kierunku przyszłych zmian w prawie międzylub ponadnarodowym. Jest przykładem typu prawa globalnego w nowym rozumieniu - efektywnie (co niekoniecznie oznacza zawsze praworządnie czy sprawiedliwie) działającym systemem normatywnym, nieskrępowanym granicami państwowymi i realnie operujacym zasadniczo poza jurysdykcją państwa. Stanowić może potencjalnie samolegitymizujacy i samoreprodukujacy się (głównie za sprawą orzecznictwa CAS) system norm prawnych i pozaprawnych, regulujących kompleksowo uniwersalnie ważną dziedzinę ludzkiej aktywności. Tylko jednak upływ czasu pozwoli rozstrzygnąć, czy lex sportiva jest melodią przyszłości, za którą będą mogły i chciały podążyć inne reżimy regulacyjne.

dr Tomasz Widtak

Uniwersytet Gdański

tomasz.widlak@prawo.ug.edu.pl 


\section{SOME COMMENTS ON THE NATURE AND STATUS OF LEX SPORTIVA WITHIN THE STRUCTURE OF INTERNATIONAL LAW}

\section{Sum mary}

The article presents the legal nature and place of sports law within the structure of international law. It reflects on the types of sources of law, the objective and subjective (institutional) scope of sports law at the international level, as well as raises the question of the need to systematise the terminology as far as concepts such as international sports order and international system of sports are concerned. The author attempts to approximate the definition of lex sportiva and presents selected comments and observations on this notion's classification as falling under the headings of - accordingly - international, transnational, global and transnational law. In the final section he argues that the best description of lex sportiva would be the one in terms of global administrative law. He also points to its innovative features, which could constitute a potentially attractive model lex ferenda for other future regimes within the new global law. 